\title{
Modeling UBC intrinsic excitability
}

\author{
Sathyaa Subramaniyam ${ }^{1,2^{*}}$, Paola Perin ${ }^{1}$, Sergio Solinas ${ }^{3}$, Egidio D'Angelo ${ }^{1,3}$ \\ From Twentieth Annual Computational Neuroscience Meeting: CNS*2011 \\ Stockholm, Sweden. 23-28 July 2011
}

Unipolar brush cells (UBCs) are excitatory glutamatergic interneurons of the cerebellar granular layer receiving both primary and secondary vestibular inputs through mossy fibers (excitatory input) and Golgi axon (inhibitory input). The brush like structure of the dendrite allows to form a giant synapses in the glomerulus and to produce an all or none post synaptic response with short delay and protracted kinetics. The excitable response of UBCs can be either a tonic discharge or a high-frequency burst of action potentials. When injected with progressively increasing depolarizing currents from a negative membrane potential, the UBC generates a burst sustained by a calcium spike (Figure $1,+20 \mathrm{pA}$ ) and then a protracted discharge with shorter latency and spike frequency adaption (Figure $1,+25 \mathrm{pA}$ ). The intrinsic excitability of UBCs is determined by an $\mathrm{H}$ current and by Low Voltage activated and High Voltage activated calcium currents [2,3]. Fast inactivating T-type Calcium channels generate low-threshold spikes and Ltype Calcium channel sustain tonic firing. The $\mathrm{H}$ current (activated between $-60 \mathrm{mV}$ and $-80 \mathrm{mV}$ ) produces a slow hyperpolarization characterized by a "sag" in response to a hyperpolarizing step (Figure 1, -16pA) and an afterhyperpolarization at the end of a depolarizing step.

\section{Conclusions}

Here we present a biologically realistic multi-compartmental mathematical model of the UBC realized with the NEURON simulator. According to literature [1-4], ionic channels are distributed among compartments (soma, dendrite, and axon). The model can reproduce the excitable properties of UBCs in current-clamp and voltage-clamp modes. Attempts at modeling the response to mossy fiber inputs are ongoing. This model confirms the primary role of the aforementioned

'Department of Physiology, University of Pavia, Via Forlanini 6, I-27100, Pavia, Italy

Full list of author information is available at the end of the article

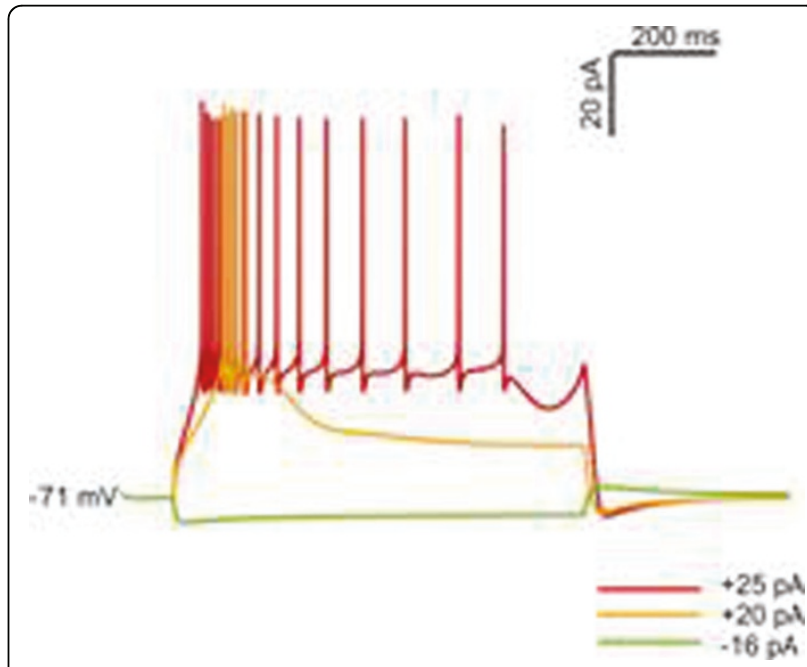

Figure 1 Excitable response of the UBC model to step-current injection.

currents in UBC's electroresponsiveness. The model will also be a valuable tool for investigating the UBC's function in the cerebellar network.

\section{Acknowledgements}

This work was supported by the EU projects CEREBNET and REALNET to ED. $\mathrm{SS}$ is recipient of a grant from CEREBNET.

\section{Author details}

'Department of Physiology, University of Pavia, Via Forlanini 6, I-27100, Pavia, Italy. ${ }^{2}$ Consorzio Interuniversitario per le Scienze Fisiche della MateriaÂA (CNISM), Via Bassi 6,ÂA I-27100 Pavia, Italy. ${ }^{3}$ Brain Connectivity Center, Istituto Neurologico IRCCS C. Mondino, Via Mondino 2, 1-27100 Pavia, Italy.

Published: 18 July 2011

\section{References}

1. Rossi DJ, Altford S, Mugnaini E, Slater NT: Properties of transmission at a giant glutamatergic synapse in cerebellum: the mossy fiber-unipolar brush cell synapse. J. Neurophysiol 1995, 74(1):24-42.

2. Diana MA, Otsu Y, Maton G, Collin T, Chat M, Dieudonné S: T-type and Ltype $\mathrm{Ca} 2+$ conductances define and encode the bimodal firing pattern

\section{Ciomed Central}


of vestibulocerebellar unipolar brush cells. J Neurosci 2007,

27(14):3823-3838.

3. Russo MJ, Yau HJ, Nunzu MG, Mugnaini E, Martina M: Dynamic

metabotropic control of intrinsic fring in cerebellar unipolar brush cells.

J Neurophysiol 2008, 100(6):3351-3360.

4. Ruigrok TJH, Henshroek RA, Simpson JI: Spontaneous activity signatures of morphologically identified interneurons in the vestibulocerebellum. The Journal of Neuroscience 2011, 31(2):712-724.

doi:10.1186/1471-2202-12-S1-P322

Cite this article as: Subramaniyam et al:: Modeling UBC intrinsic excitability. BMC Neuroscience 2011 12(Suppl 1):P322.

Submit your next manuscript to BioMed Central and take full advantage of:

- Convenient online submission

- Thorough peer review

- No space constraints or color figure charges

- Immediate publication on acceptance

- Inclusion in PubMed, CAS, Scopus and Google Scholar

- Research which is freely available for redistribution

Submit your manuscript at www.biomedcentral.com/submit 